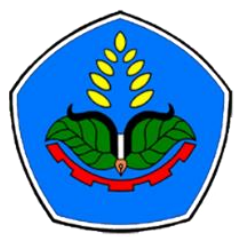

AGROPROSS

National Conference

Proceedings of Agriculture

\section{Proceedings: \\ Peran Teaching Factory Di Perguruan Tinggi Vokasi Dalam Mendukung Ketahanan Pangan Pada Era New Normal}

Tempat : Politeknik Negeri Jember

Tanggal : 8-9 Juli 2020

\section{Publisher:}

Agropross, National Conference Proceedings of Agriculture

ISBN : 978-623-94036-6-9

DOI : 10.25047 /agropross.2020.40

\title{
Seleksi dan Karakterisasi Pertumbuhan Cendawan Tanah Penghasil Enzim Protease Asal Rhizosfer Padi di Tarakan - Kalimantan Utara
}

\author{
Author(s): Muh Adiwena ${ }^{(1) *}$, Mardhiana ${ }^{(1)}$, Aditya Murtilaksono ${ }^{(1)}$, Dwi Santoso ${ }^{(1)}$, \\ Rizza Wijaya $^{(2)}$, Ankardiansyah Pandu Pradana ${ }^{(3)}$
}

(1) Program Studi Agroteknologi, Fakultas Pertanian, Universitas Borneo Tarakan

(2) Jurusan Teknologi Pertanian, Program Studi Keteknikan Pertanian, Politeknik Negeri Jember

(3) Program Studi Proteksi Tanaman, Fakultas Pertanian, Universitas Jember

* Corresponding author: melaapriyani28@gmail.com

\begin{abstract}
Soil fungi play an essential role in the sustainable agriculture system. Their ability to produce various metabolite compounds makes them as one of the potential biological control agents against plant pathogens. One of the fungi secondary metabolites that are anti-pathogenic is the extracellular protease enzyme. This enzyme can degrade the cell wall of pathogenic fungi, nematodes, and nematode eggs. Soil samples were taken from 5 sampling points on farmers' paddy fields in Mamburungan Village, Tarakan City, North Kalimantan. Fungi isolation was conducted using potato dextrose agar (PDA) at $37^{\circ} \mathrm{C}$ at the Plant Protection Laboratory, University of Borneo Tarakan. Their macroscopic shape visually characterizes isolated fungi. The proteolytic activity test was carried out using a PDA media supplemented with skim milk. All fungi that grow then characterized by their growth speed for 11 days. The results showed that seven fungi isolates were successfully isolated, and $3(48.85 \%)$ were able to produce protease enzymes. Isolates that can produce protease enzymes are isolates C5, C6, and C7. Furthermore, based on its growth character, the seven isolates obtained showed mixed responses. On the 11th day, the highest growth was shown by isolates C1, C2, C5, and C6 with a diameter of $8.5 \mathrm{~cm}$. The slowest growth was shown by $C 7$ isolate with a diameter of $2.53 \mathrm{~cm}$. This study provides information that there are proteolytic fungi from the rice rhizosphere at the study site with diverse growth characters.
\end{abstract}

Keyword:

Diameter;

Extracellular;

Isolate;

Macroscopic;

Proteolytic

\section{Kata Kunci:}

Diameter;

Ekstraseluler;

Isolat;

Makroskopis;

Proteolitik;

\begin{abstract}
ABSTRAK
Cendawan tanah memegang peran esensial dalam budidaya pertanian berkelanjutan. Kemampuannya dalam memproduksi berbagai senyawa metabolit menjadikan cendawan sebagai salah satu agens hayati yang potensial untuk mengendalikan patogen tanaman. Salah satu metabolit sekunder cendawan yang bersifat antipatogen adalah enzim ekstraseluler protease. Enzim ini dapat mendegradasi dinding sel cendawan patogen, nematoda, dan telur nematoda. Penelitian ini bertujuan untuk mengisolasi cendawan penghasil enzim protease dari rhizosfer padi dan mengkarakterisasi pertumbuhannya. Sampel tanah diambil dari 5 titik pengambilan sampel pada lahan padi petani di Kelurahan Mamburungan, Kota Tarakan, Kalimantan Utara. Isolasi dilakukan menggunakan media potato dextrose agar (PDA) pada suhu $37^{\circ} \mathrm{C}$ di Laboratorium Perlindungan Tanaman, Universitas Borneo Tarakan. Cendawan yang tumbuh dikarakterisasi bentuk makroskopisnya secara visual. Pengujian aktivitas proteolitik dilakukan menggunakan media PDA yang ditambah dengan skim milk. Seluruh cendawan yang tumbuh kemudian dikarakterisasi kecepatan tumbuhnya selama 11 hari. Hasil penelitian menunjukkan terdapat 7 isolat cendawan yang berhasil diisolasi, dan $3(48,85 \%)$ diantaranya mampu menghasilkan enzim protease. Isolat yang mampu menghasilkan enzim protease adalah isolat C5, C6, dan C7. Selanjutnya, berdasarkan karakter pertumbuhannya, tujuh isolat yang diperoleh menunjukkan respon yang beragam. Pada hari ke-11, pertumbuhan tertinggi ditunjukkan oleh isolat $\mathrm{C} 1, \mathrm{C} 2, \mathrm{C} 5$, dan $\mathrm{C} 6$ dengan diameter $8,5 \mathrm{~cm}$. Pertumbuhan paling lambat ditunjukkan oleh isolat $\mathrm{C} 7 \mathrm{dengan}$ diameter $2,53 \mathrm{~cm}$. Penelitian ini memberikan informasi bahwa terdapat cendawan proteolitik dari rhizosfer padi pada lokasi penelitian dengan karakter pertumbuhan yang beragam.
\end{abstract}




\section{PENDAHULUAN}

Pertumbuhan tanaman dipengaruhi oleh berbagai macam faktor yang ada disekitarnya, baik itu dari media tanam maupun kondisi tanahnya. Media tanam dan kondisi tanah ini memiliki karakteristik yang berbeda-beda sesuai dengan apa yang terkandung didalamnya (Wijaya et al., 2020). Keragaman mikroba merupakan salah satu faktor yang memiliki peran penting dalam status kesehatan tanah(El Mujtar et al., 2019). Tanah yang sehat merupakan suatu kondisi dimana populasi mikroba di tanah seimbang sehingga tidak terjadi ledakan populasi yang berpotensi menyebabkan infeksi pada tanaman(Karlen et al., 2019). Keseimbangan mikroba di dalam tanah dapat terjadi karena beberapa mikroba saling menekan pertumbuhan satu dengan yang lainnya. Penekanan pertumbuhan dapat terjadi melalui beberapa mekanisme seperti persaingan relung hidup, persaingan nutrisi, dan sekresi senyawa anti-mikroba (metabolit sekunder)(Vimal et al., 2017; Smith et al., 2018).

Cendawan dikenal sebagai salah satu mikroba yang dapat menghasilkan berbagai macam metabolit sekunder. Metabolit sekunder cendawan merupakan senyawa organik yang tidak terlibat secara langsung dalam pertumbuhan, perkembangan, dan reproduksi suatu cendawan(He et al., 2018). Metabolit sekunder yang dihasilkan oleh Trichoderma sp. antara lain pachybasin, trichodermol, senyawa antibiotik, enzim ekstraseluler (protease, 1,3- $\beta$ glukanaseselulase, selobiase, dan kitinase), 2,3-dihidroksi-5,6-dimetil benzokuinon, asam ferulat, asam harzianat, dan 1,2dimetil-3,4-dihidroksi benzene(Pascale et al., 2017). Selain Trichoderma, cendawan lain yang dikenal mampu memproduksi metabolit sekunder adalah Beauveria bassiana, Gliocladium, dan Metharizium(Lozano-Tovar et al., 2017).
Salah satu metabolit sekunder cendawan yang memiliki potensi untuk dikembangkan sebagai pelindung tanaman adalah enzim ektraseluler protease. Enzim protease merupakan enzim yang dapat menghidrolisis dan menghancurkan protein dan memecah menjadi molekul yang lebih sederhana. Enzim protease merupakan salah satu senyawa yang berperan penting dalam pengendalian beberapa cendawan patogen tanaman dan nematoda parasit tanaman(Suarez et al., 2004).Enzim protease dapat menghidrolisis dinding sel nematoda Meloidogyne spp. dan menghancurkan lapisan terluar telur nematoda Meloidogyne spp., Pratylenchus sp., dan Radopholus sp. (Sahebani dan Hadavi, 2008).

Pada studi yang telah dilakukan oleh beberapa peneliti, diketahui bahwa cendawan penghasil enzim protease dapat ditapis dari rhizosfer berbagai tanaman(Wade dan Beuchat, 2003). Pada laporan terpisah juga dijelaskan bahwa kuantitas enzim protease yang dihasilkan oleh cendawan pada umumnya berkorelasi positif dengan kecepatan tumbuh cendawan. Penelitian ini merupakan penelitian pendahuluan yang bertujuan untuk memperoleh kandidat isolat cendawan yang berpotensi memproduksi enzim protease dan mengkarakterisasi karakter pertumbuhannya.

\section{BAHAN DAN METODE}

Penelitian dilakukan di Laboratorium Perlindungan Tanaman, Fakultas Pertanian, Universitas Borneo Tarakan pada bulan November - Desember 2017. Teknik pengambilan sampel yaitu dengan titik sampel tersebar menyerupai huruf "X" di area persawahan. Sebanyak $50 \mathrm{~g}$ tanah yang terletak di kedalaman $5-10 \mathrm{~cm}$ diambil dari 5 titik sampel. Tanah kemudian dikompositkan menggunakan $200 \mathrm{ml}$ akuades steril lalu didiamkan selama 30 menit. Isolasi dan Purifikasi 
Isolat Cendawan dengan cara mengambil sebanyak $100 \mu \mathrm{l}$ suspensi sampel dihomogenkan dan diambil, kemudian dituangkan pada cawan berisi media Potato Dextrose Agar (PDA) yang telah disterilisasi menggunakan autoklaf. Suspensi kemudian diinkubasi selama 7 hari pada suhu $32{ }^{\circ} \mathrm{C}$. Cendawan yang tumbuh pada media PDA dan memiliki karakter fenotip yang berbeda kemudia dimurnikan menggunakan cork borer. Pemurnian dilakukan dengan memindahkan bagian ujung cendawan pada media PDA yang baru. Seluruh kegiatan isolasi dan purifikasi dilakukan secara aseptis pada laminar air flow(Abri, 2015).

Isolat cendawan murni diambil menggunakan cork borer steril berdiameter $0,3 \mathrm{~cm}$ dan ditumbuhkan pada media PDA menggunakan cawan petri berdiameter $9 \mathrm{~cm}$. Cendawan ditumbuhkan tepat pada bagian tengah cawan petri dan diinkubasi pada suhu $32{ }^{\circ} \mathrm{C}$ selama 11 hari. Pengukuran pertumbuhan cendawan dilakukan setiap hari dengan mengukur diameter cendawan $(\mathrm{cm})$ secara horizontal dan vertikal (Achmad dan Suryana, 2009).

$$
\text { Aktivitas proteolitik diuji }
$$

menggunakan media PDA yang diperkaya dengan susu skim. Media PDA steril yang telah disiapkan diencerkan dan didiamkan sampai suhu $50{ }^{\circ} \mathrm{C}$. Selanjutnya, ketika media PDA berada pada suhu $50{ }^{\circ} \mathrm{C}$ ditambahkan dengan suspensi susu skim $(9: 1, \mathrm{v} / \mathrm{v})$. Susu skim yang digunakan adalah susu skim komersial yang kemudian dipasteurisasi sampai dengan suhu $70{ }^{\circ} \mathrm{C}$ (Mardhiana et al., 2017). Media uji kemudian dituangkan pada cawan petri berdiameter $9 \mathrm{~cm}$. Isolat cendawan yang diuji kemudian diambil menggunakan cork borer berdiameter $0,1 \mathrm{~cm}$ dan cendawan yang terambil ditumbuhkan pada bagian tengah cawan petri. Pengujian dilakukan selama 48 jam pada suhu $32{ }^{\circ} \mathrm{C}$. Cendawan yang memiliki aktivitas proteolitik ditandai dengan terbentuknya zona bening di sekitar titik tumbuh cendawan (Michel et al., 1993).

Data dianalisis secara deskriptif dan disajikan dalam bentuk tabel dan gambar.

\section{HASIL DAN PEMBAHASAN Isolat Cendawan}

Sebanyak tujuh isolat cendawan berhasil diisolasi dan dimurnikan. Ketujuh cendawan tersebut kemudian diberi kode isolat sebagai $\mathrm{C} 1, \mathrm{C} 2, \mathrm{C} 3, \mathrm{C} 4, \mathrm{C} 5, \mathrm{C} 6$, dan C7. Berdasarkan pengamatan makroskopis, isolat cendawan yang diperoleh pada penelitian ini memiliki karakter bentuk, warna, elevasi, dan tepian yang beragam. Seluruh cendawan yang diperoleh memiliki elevasi datar. Hanya ada dua jenis tepian dan bentuk yang diperlihatkan oleh keseluruhan cendawan yang diisolasi. Isolat cendawan $\mathrm{C} 2$ dan $\mathrm{C} 3$ memiliki tepian tipe Ciliate dan hanya $\mathrm{C} 3$ yang berbentuk tidak teratur. Lebih lanjut, karakter isolat cendawan yang berhasil diisolasi pada penelitian ini disajikan pada Tabel 1.

\section{Karakter Pertumbuhan}

Berdasarkan hasil pengamatan diketahui bahwa setiap isolat memiliki karakter pertumbuhan yang beragam. Pada hari pertama pengamatan diketahu bahwa isolat $\mathrm{C} 2$ menunjukkan pertumbuhan paling tinggi dengan diameter cendawan mencapai $2,5 \mathrm{~cm}$. Isolat $\mathrm{C} 2$ menunjukkan pertumbuhan yang signifikan pada hari ke2 dan ke-3 dan mencapai titik pertumbuhan maksimum di hari ke-3 dengan diameter $8,5 \mathrm{~cm}$. Pada hari ke-4 sampai dengan ke11 pengamatan, isolat $\mathrm{C} 2$ tidak menunjukkan perubahan ukuran diameter. Selanjutnya, isolat lainnya yang menunjukkan pertumbuhan cukup cepat adalah isolat $\mathrm{C} 1$. Isolat $\mathrm{C} 1$ memiliki diameter $0,78 \mathrm{~cm}$ pada hari pertama pengamatan, kemudian mencapai diameter maksimum pada $8,5 \mathrm{~cm}$ di hari ke- 8 pengamatan. Selain isolat $\mathrm{C} 2$ dan $\mathrm{C} 1$, isolat lain yang menunjukkan pertumbuhan yang 

Pandu Pradana

signifikan adalah isolat C5 dan C6 yang mencapai diameter maksimum pada hari ke-11 pengamatan. Isolat dengan diameter terkecil sampai pada akhir pengamatan adalah isolat $\mathrm{C} 7$ dengan diameter $2,53 \mathrm{~cm}$ pada pengamatn hari ke-11. Lebih lanjut, data pertumbuhan cendawan disajikan pada Gambar 1

Tabel 1. Karakteristik Makroskopis Cendawan

\begin{tabular}{ccccc}
\hline Kode & Bentuk & Warna & Elevasi & Tepian \\
\hline C1 & Tidak Teratur & Hitam & Datar & Lobate \\
C2 & Tidak Teratur & Putih & Datar & Ciliate \\
C3 & Teratur & Oranye & Datar & Ciliate \\
C4 & Tidak Teratur & Putih & Datar & Lobate \\
C5 & Tidak Teratur & Oranye & Datar & Lobate \\
C6 & Tidak Teratur & Abu-abu & Datar & Lobate \\
C7 & Tidak Teratur & Abu-abu & Datar & Lobate \\
\hline
\end{tabular}

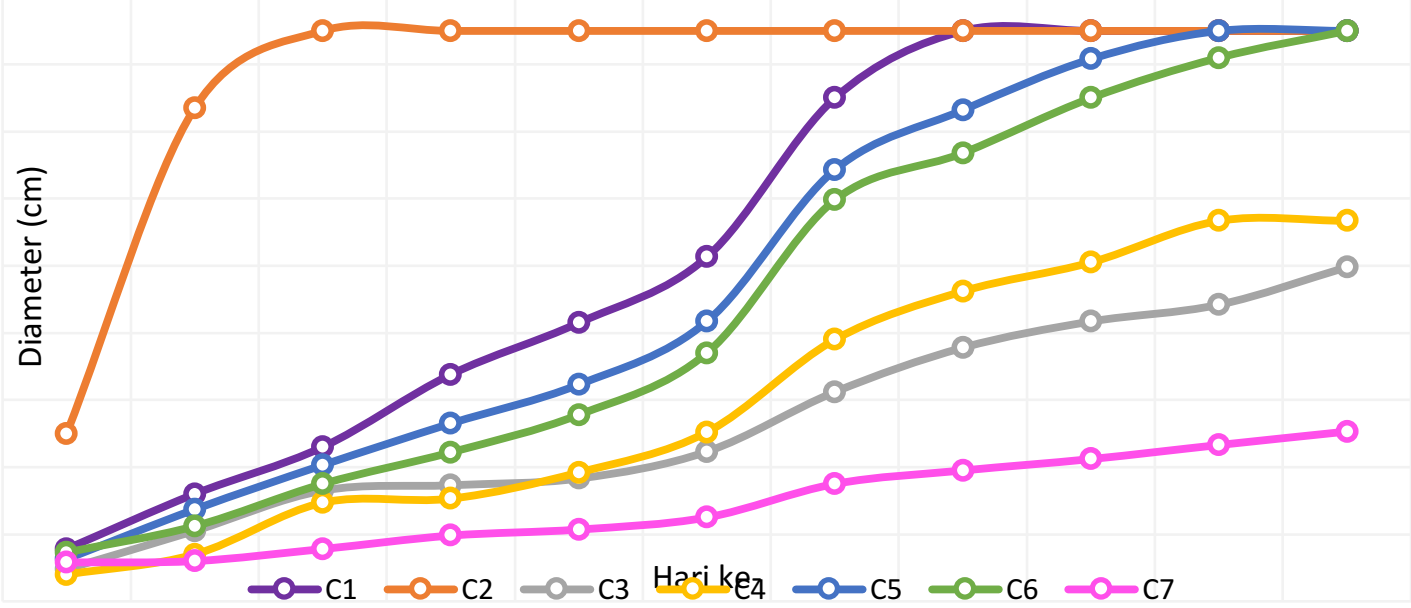

Gambar 1. Grafik pertumbuhan isolat cendawan asal rhizosfer padi 

Pandu Pradana

Tabel 2. Pertambahan Diameter Cendawan

\begin{tabular}{|c|c|c|c|c|c|c|c|c|c|c|c|}
\hline \multirow{2}{*}{ Kode } & \multicolumn{11}{|c|}{ Pertambahan Diameter Per Hari $(\mathrm{cm})$} \\
\hline & 1 & 2 & 3 & 4 & 5 & 6 & 7 & 8 & 9 & 10 & 11 \\
\hline $\mathrm{C} 1$ & 0,78 & 0,82 & 0,70 & 1,08 & 0,77 & 0,98 & 2,37 & 1,00 & 0,00 & 0,00 & 0,00 \\
\hline $\mathrm{C} 2$ & 2,50 & 4,85 & 1,15 & 0,00 & 0,00 & 0,00 & 0,00 & 0,00 & 0,00 & 0,00 & 0,00 \\
\hline $\mathrm{C} 3$ & 0,48 & 0,37 & 0,43 & 0,37 & 0,37 & 0,40 & 0,88 & 0,67 & 0,38 & 0,25 & 0,57 \\
\hline $\mathrm{C} 4$ & 0,40 & 0,23 & 0,58 & 0,40 & 0,45 & 0,60 & 1,38 & 0,72 & 0,43 & 0,62 & 0,00 \\
\hline C5 & 0,63 & 0,73 & 0,67 & 0,62 & 0,58 & 0,93 & 2,27 & 0,88 & 0,77 & 0,42 & 0,00 \\
\hline C6 & 0,73 & 0,38 & 0,63 & 0,47 & 0,57 & 0,92 & 2,28 & 0,70 & 0,82 & 0,60 & 0,40 \\
\hline C7 & 0,75 & 0,07 & 0,18 & 0,20 & 0,08 & 0,18 & 0,50 & 0,20 & 0,17 & 0,22 & 0,20 \\
\hline
\end{tabular}

Berdasarkan data pertmbuhan pada Gambar 1, dapat diketahui rata-rata pertamabahan diameter cendawan setiap harinya. Pertambahan diameter tertinggi terdapat pada isolat $\mathrm{C} 2$ di hari ke-2, yaitu bertambah 4,85 $\mathrm{cm}$ dibandingkan dengan hari sebelumnya. Selanjutny pada hari ke7 pengamatan, isolat $\mathrm{C} 1$ juga menunjukkan perubahan diameter cendawan yang signifikan, yaitu $2,37 \mathrm{~cm}$. Selain itu, isolat C5 juga menunjukkan perubahan signifikan pada har ke-5 dengan pertambahan diamater $2,27 \mathrm{~cm}$. Isolat lainnya menunjukkan data perubahan diameter cendawan yang beragam namun stabil di bawah $1 \mathrm{~cm}$. Lebih lanjut, data pertambahan diameter cendawan disajikan pada Tabel 2.

\section{Aktivitas Proteolitik}

Hasil uji aktivitas proteolitik menunjukkan terdapat tiga isolat yang mampu memproduksi enzim ekstraseluler protease. Ketiga isolat tersebut adalah isolat C5, C6, dan C7. Aktivitas proteolitik ditunjukkan oleh adanya zona bening di sekitar cendawan. Pada 48 jam inkubasi, secara kualitatif isolat C7 menunjukkan aktivitas proteolitik yang lebih tinggi, ditunjukkan dengan zona bening yang lebih besar dibandingkan dengan isolat lainnya. Kemudian, setelah isolat C7, secara kualitatif produksi enzim protease lebih baik pada isolat $\mathrm{C} 6$ dan $\mathrm{C} 5$. Isolat lainnya $(\mathrm{C} 1, \mathrm{C} 2, \mathrm{C} 3$, dan $\mathrm{C} 4)$ tidak menunjukkan aktivitas proteolitik. Lebih lanjut, hasil pengujian aktivitas proteolitik disajikan pada Gambar 2.

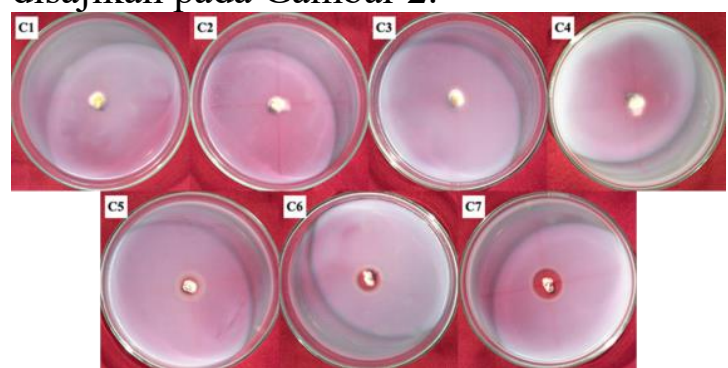

Gambar 2. Hasil uji aktivitas proteolitik cendawan asal rhizosfer padi

\section{Pembahasan}

Cendawan tanah sudah umum digunakan sebagai agens pengendali hayati dalam dunia perlindungan tanaman. Kemampuannya hidup pada berbagai substrat menjadi salah satu alasan cendawan sering digunakan sebagai agens pengendali hayati. Namun demikian, Cendawan dapat diisolasi dari berbagai sumber seperti tanah, permukaan tanaman(Zahn dan Amend, 2019), dari dalam jaringan tanaman (endofit)(Deng dan Cao, 2017), dan dari benih(Youssef et al., 2018). Pada penelitian sebelumnya Batista et al. (2016)berhasil mengisolasi cendawan dari rhizosfer padi. Penelitian tersebut memperkuat hasil dari penelitian ini yang juga memperoleh cendawan dari rhizosfer tanaman padi(Pradana, 2016).

Cendawan memiliki peran penting dalam menjaga keseimbangan ekosistem dan menjaga kesuburan tanah (Vezzani et al., 2018). Produk metabolit yang 
dihasilkan oleh cendawan memiliki peran esensial dalam dunia pertanian. Keberadaan cendawan yang memproduksi enzim selulase dapat membantu proses pelapukan bahan organik di dalam tanah dan mempercepat proses dekomposisi bahan organik (Větrovský et al., 2016). Cendawan yang memproduksi enzim kitinase dapat berperan secara langsung dalam menjaga kesehatan tanaman melalui penekanan mikroba patogen menggunakan enzim kitinase (Langner dan Göhre, 2016). Demikian pula dengan cendawan yang memproduksi enzim protease, golongan cendawan proteolitik berperan dalam menjaga kesehatan tanaman secara langsung (Elad dan Kapat, 1999).

Enzim protease dikenal sebagai salah satu enzim yang efektif dalam menekan berbagai jenis patogen. Mikroba penghasil enzim protease saat ini banyak dimanfaatkan sebagai agens pelindung benih, agens biokontrol, dan agens penginduksi ketahanan tanaman (Lawrence dan Koundal, 2002). Patogen yang dapat dikendalikan menggunakan enzim protease adalah patogen yang memiliki dinding sel yang terdiri dari protein. Siddiqui et al. (2005) melaporkan nmatoda Meloidogyne incognita dapat dikendalikan menggunakan mikroba penghasil enzim protease. Selanjutnya, pada laporan terpisah Lian et al. (2007) juga melaporkan bahwa nematoda Radopholus similis dan Pratylenchus coffeae dapat dikendalikan dengan mikroba penghasil enzim protease.

Pemanfaatan metabolit sekunder seperti crude extract yang mengandung enzim protease dari mikroba akan menjadi salah satu teknik pengendalian alternatif yang efektif di masa depan. Metabolit sekunder dapat diproduksi dalam waktu yang relatif singkat, mudah, dan murah. Selain itu, pemanfaatan metabolit sekunder juga lebih efektif karena tidak terlalu terpengaruh pada kondisi lingkungan (Reino et al., 2008). Ekstraksi metabolit sekunder dan pemisahan senyawa metabolit dengan sel mikroba pada umumnya lebih mudah dilakukan pada cendawan dibandingkan dengan bakteri. Hal tersebut karena ukuran sel cendawan yang lebih besar dibandingkan dengan bakteri, sehingga proses filter menjadi lebih mudah (Bogner et al., 2017). Penelitian ini memberikan informasi baru bahwa pada rhizosfer padi di Tarakan, Kalimantan Utara terdapat cendawan proteolitik. Meskipun demikian, perlu dilakukan uji lanjut berupa uji patogenesitas untuk memastikan keamanan hayati setiap cendawan.

\section{KESIMPULAN}

Terdapat 7 isolat cendawan asal rhizosfer padi di Kota Tarakan, Kalimantan Utara, dengan karakter pertumbuhan yang beragam. Isolat yang menunjukkan pertumbuhan baik ditunjukkan oleh isolat $\mathrm{C} 2$ dan $\mathrm{C} 1$. Isolat yang mampu memproduksi enzim protease adalah isolat C5, C6, dan C7.

\section{DAFTAR PUSTAKA}

Abri, A. (2015). Isolasi cendawan rhisozfer penghasil hormone indol acetic acid (IAA) pada padi aromatik Tanatoraja. Prosiding Seminar Nasional Mikrobiologi Kesehatan dan Lingkungan (pp. 72-78). Makassar (ID), UIN Alauddin Makassar.

Achmad, A.,\&Suryana, I. (2009). Pengujian aktivitas ekstrak daun sirih (Piper betle Linn.) terhadap Rhizoctonia sp. secara in vitro.Buletin Penelitian Tanaman Rempah dan Obat, 20(1), 92-98.

Batista, B.L., Barião, C.V., Souza, J.M.O., Paulelli, A.C.C., Rocha, B.A., Anderson, R.M.O., Fabiana, R.S., Gilberto, U.L.B., Ludmilla, T., Márcia, R.V., \& Fernando, B.J.(2016). A low-cost and 
environmentally-friendly potential procedure for inorganic-As remediation based on the use of fungi isolated from rice rhizosphere. Journal of Environmental Chemical Engineering, 4(1),891-898. DOI: 10.1016/j.jece.2015.12.029.

Bogner, C.W., Kamdem, R.S., Sichtermann, G., Matthäus, C., Hölscher, D., Popp, J., Proksch, P., Grundler, F.M.W., \& Schoutencor, A.(2017). Bioactive secondary metabolites with multiple activities from a fungal endophyte. Microbial Biotechnology, 10(1), 175-188. DOI: $10.1111 / 1751-7915.12467$.

Deng, Z., \& Cao, L. (2017). Fungal endophytes and their interactions with plants in phytoremediation: a review. Chemosphere, 168(1), 1100-1106. DOI: 10.1016/j.chemosphere.2016.10.09 7.

El Mujtar, V., Muñoz, N., Mc Cormick, B.P., Pulleman, M., \&Tittonell, P. (2019). Role and management of soil biodiversity for food security and nutrition; where do we stand?.Global Food Security, 20, 132-144.

DOI: 10.1016/j.gfs.2019.01.007.

Elad, Y., \& Kapat, A. (1999). The role of Trichoderma harzianum protease in the biocontrol of Botrytis cinerea. European Journal of Plant Pathology, 105(2),177-189. DOI: 10.1023/A:1008753629207.

He, Y., Wang, B., Chen, W., Cox, R.J., He, J.,\& Chen, F. (2018). Recent advances in reconstructing microbial secondary metabolites biosynthesis in Aspergillus spp.
Biotechnology Advances, 36(3), 739-783.

DOI: 10.1016/j.biotechadv.2018.02.001.

Karlen, D.L., Veum, K.S., Sudduth, K.A., Obrycki, J.F., \&Nunes, M.R. (2019). Soil health assessment: Past accomplishments, current activities, and future opportunities. Soil and Tillage Research, 195,110.

DOI:

10.1016/j.still.2019.104365.

Langner, T., \& Göhre, V. (2016). Fungal chitinases: function, regulation, and potential roles in plant/pathogen interactions. Current Genetics, 62(2),243-254. DOI: 10.1007/s00294-015-0530-x.

Lawrence, P,K.,\& Koundal, K.R. (2002). Plant protease inhibitors in control of phytophagous insects. Electronic Journal of Biotechnology, 5(1), 5-6.

Lian, L., Tian, B., Xiong, R., Zhu, M., Xu, J., \& Zhang, K.Q.(2007). Proteases from Bacillus: a new insight into the mechanism of action for rhizobacterial suppression of nematode populations. Letters in Applied Microbiology, 45(3),262269. DOI: $10.1111 / \mathrm{j} .1472-$ 765X.2007.02184.x.

Lozano-Tovar, M., Garrido-Jurado, I., Quesada-Moraga, E., Raya-Ortega, M., \&Trapero-Casas, A. (2017). Metarhizium brunneum and Beauveria bassiana release secondary metabolites with antagonistic activity against Verticillium dahliae and Phytophthora megasperma olive pathogens. Crop Protection, 100,186-195. DOI: 10.1016/j.cropro.2017.06.026. 
Mardhiana, M., Pradana, A. P., Adiwena, M., Santoso, D., Wijaya, R., \& Murtilaksono, A. (2017). Use of endophytic bacteria from roots of Cyperus rotundus for biocontrol of Meloidogyne incognita. Biodiversitas Journal of Biological Diversity, 18(4), 1308-1315. DOI: 10.13057/biodiv/d180404.

Michel, V., Fonty, G., Millet, L., Bonnemoy, F., \&Gouet, P. (1993). In vitro study of the proteolytic activity of rumen anaerobic fungi. FEMS Microbiology Letters, 110(1), 5-9. DOI:10.1111/j.15746968.1993.tb06287.x.

Pascale, A., Vinale, F., Manganiello, G., Nigro, M., Lanzuise, S.,Ruocco, M., Lombardi, N., \& Woo, S.L. (2017). Trichoderma and its secondary metabolites improve yield and quality of grapes. Crop Protection, 92,176-181. DOI: 10.1016/j.cropro.2016.11.010.

Pradana, A. (2016). Konsorsium bakteri endofit sebagai agens biokontrol Nematoda Puru Akar Meloidogye incognita pada Tomat. Tesis]. Bogor: Sekolah Pascasarjana. Institut Pertanian Bogor.

Retieved form :

https://repository.ipb.ac.id/handle/ 123456789/82174

Reino, J.L., Guerrero, R.F., HernándezGalán, R.,\&Collado, I.G. (2008). Secondary metabolites from species of the biocontrol agent Trichoderma. Phytochemistry Reviews, 7(1), 89-123. DOI: 10.1007/s11101-006-9032-2.

Sahebani, N., \&Hadavi, N. (2008). Biological control of the root-knot nematode Meloidogyne javanica by Trichoderma harzianum. Soil Biology and Biochemistry. 40(8), 2016-2020.

DOI: 10.1016/j.soilbio.2008.03.011.

Siddiqui, I.A., Haas, D., \& Heeb, S. (2005). Extracellular protease of Pseudomonas fluorescens CHA0, a biocontrol factor with activity against the root-knot nematode Meloidogyne incognita. Applied and Environmental Microbiology, 71(9), 5646-5649. DOI: 10.1128/AEM.71.9.56465649.2005 .

Smith, M.E., Facelli, J.M., \& Cavagnaro, T.R. (2018). Interactions between soil properties, soil microbes and plants in remnant-grassland and old-field areas: a reciprocal transplant approach. Plant and Soil, 433(1-2),127-145. DOI: 10.1007/s11104-018-3823-2.

Suarez, B., Rey, M., Castillo, P., Monte, E., \& Llobell, A. (2004). Isolation and characterization of PRA1, a trypsin-like protease from the biocontrol agent Trichoderma harzianum CECT 2413 displaying nematicidal activity. Applied Microbiology and Biotechnology, 65(1), 46-55. DOI: 10.1007/s00253-004-1610-x.

Větrovský, T., Štursová, M., \& Baldrian, P. (2016). Fungal communities in soils: soil organic matter degradation. Di dalam Martin, F., \& Uroz, S (eds). Microbial Environmental Genomics (MEG)(pp. 89-100). Springer, UK.

Vezzani, F.M., Anderson, C., Meenken, E., Gillespie, R., Peterson, M., \& Beare, M.H. (2018). The 
importance of plants to development and maintenance of soil structure, microbial communities and ecosystem functions. Soil and Tillage Research, 175,139-149. DOI: 10.1016/j.still.2017.09.002.

Vimal, S.R., Singh, J.S., Arora, N.K., \& Singh, S. (2017). Soil-plantmicrobe interactions in stressed agriculture management: a review. Pedosphere, 27(2), 177-192. DOI: 10.1016/S1002-0160(17)60309-6.

Wade, W.N., \&Beuchat, L.R. (2003). Proteolytic fungi isolated from decayed and damaged raw tomatoes and implications associated with changes in pericarp $\mathrm{pH}$ favorable for survival and growth of foodborne pathogens. Journal of Food Protection, 66(6), 911-917.DOI: 10.4315/0362-028x66.6.911.

Youssef, M.A., Aly, A., Tohamy, M., \& Ghonim, M. (2018). Studies on fungi associated with pea seeds and their effect on germination and some seed characters. Zagazig Journal of Agricultural Research, 45(4), 1291-1308. DOI: 10.21608/zjar.2018.48574.

Zahn, G., \&Amend, A.S. (2019). Foliar fungi alter reproductive timing and allocation in Arabidopsis under normal and water-stressed conditions. Fungal Ecology, 41, 101106. DOI:

10.1016/j.funeco.2019.04.002. 